\title{
Diabetes and Vernonia amygdalina Delile (Asteraceae)
}

\author{
Udyanee Jayaweera ${ }^{1, * \mathbb{D}}$, Gabriel Akyirem Akowuah ${ }^{1, * \mathbb{D}}$, Chew Yik Ling 1(D), Palanirajan Vijayaraj \\ Kumar $^{1}$ (D), Sajeewa Herapathdeniya 2 (D) \\ 1 Faculty of Pharmaceutical Sciences, UCSI University, No. 1, Jalan Menara Gading, 56000, Cheras, Kuala Lumpur, \\ Malaysia; agabriel@ucsiuniversity.edu.my (G.A.A.); \\ 2 Institute of Indigenous Medicine, University of Colombo, Rajagiriya, Sri Lanka; herapathdeniyaskmk@gmail.com (S.H.); \\ * Correspondence: agabriel@ucsiuniversity.edu.my (G.A.A.), udyanee96@gmail.com (U.J.);
}

Scopus Author ID 55887540600

Received: 11.08.2021; Revised: 14.09.2021; Accepted: 17.09.2021; Published: 3.10.2021

\begin{abstract}
Vernonia amygdalina, is a perennial tropical shrub from Asteraceae with a height ranging from 1 to $10 \mathrm{~m}$ tall. In Tropical African Countries, V. amygdalina, known as bitter leaf because of the bitter taste of the leaf, is propagated for consumption as a vegetable due to its medicinal properties.

In this paper, the use of the plant $V$. amygdalina for the treatment of diabetes mellitus is reviewed by searching scientific databases such as Frontiers, HealthSTAR, MDPI, MEDLINE, Pubmed, Taylor and Francis, Science Direct, Scopus, Springer, Wiley, American Diabetes Association from 2000 to January 2021. Herbal medicine is a form of healthcare that has been used in diabetes treatment. One such herbal plant is $V$. amygdalina, a multipurpose plant with many uses, health benefits, and bioactivities. $V$. amygdalina is identified as the most medically beneficial plant in the genus Vernonia. V. amygdalina possesses several activities, including the anti-diabetic effect. This review discusses classifications and treatments (conventional and herbal) of diabetes mellitus, the phytochemical profile of $V$. amygdalina and its uses in the treatment of diabetes mellitus, and their mechanisms of action of the plant. The published literature used for the present work supports anti-diabetic properties of $V$. amygdalina.
\end{abstract}

Keywords: Diabetes mellitus; medicinal plants; Vernonia amygdalina.

(C) 2021 by the authors. This article is an open-access article distributed under the terms and conditions of the Creative Commons Attribution (CC BY) license (https://creativecommons.org/licenses/by/4.0/).

\section{Introduction}

Diabetes mellitus is a metabolic disorder where the blood glucose level becomes elevated if the pancreas is unable to produce enough insulin or its activity of promoting glucose uptake is resisted by the cells. Many synthetic drugs are available for the management of diabetes, but these therapies seem to be insufficient to prevent diabetic complications in type2 diabetes, with a likelihood of developing cardiovascular events. Because of these limitations, there is a continuous need to develop novel health promotion strategies and therapeutic modalities. Despite the large armamentarium presently available, the progressive deterioration of diabetes control is such that treatment is still insufficient. The majority of type- 2 diabetes patients eventually require insulin therapy to achieve targeted glycemic levels, and an estimated $75 \%$ dying diabetes-related complications from cardiovascular disease. Insufficiency of current therapies for the treatment of diabetes, combined with side effects of conventional medical treatment and an inability of the economy to absorb the cost of pharmaceuticals, have created a growing public interest in dietary supplements and botanicals [1]. Thus, diabetes patients rely on alternative medicine. 
Traditional medicine has been used for diabetes management in many countries. Compared to prescription drugs, the herbs required are readily available, cost-effective, and have very low side effects. The plants present their anti-diabetic activity by either inhibiting enzymes involved in glucose generation or promoting insulin secretion. Secondary metabolites such as glycosides, alkaloids, terpenoids, and flavonoids present in plants contribute to the antidiabetic activity. Over the years, the use of traditional herbal medicine for the treatment and prevention of various diseases, including diabetes, has become popular. The techniques of herbal medicine for use requires preparation of decoctions, syrups, extracts, or tincture using plant roots, leaves, barks or flowers [2].

For the management of diabetes mellitus, more than 800 medicinal plants have been studied and are being used for treatment globally. This is due to their effectiveness, low side effects compared to conventional pharmacotherapy, and relatively low costs [3]. Vernonia amygdalina (VA) is one such herb that is known for its anti-diabetic qualities. This review will stimulate further research on V. amygdalina and diabetes treatments.

\section{Materials and Methods}

The data for the current article were obtained by searching scientific databases such as Frontiers, HealthSTAR, MDPI, MEDLINE, Pubmed, Taylor and Francis, Science Direct, Scopus, Springer, Wiley, American Diabetes Association from 2000 to January 2021 using the following keywords: Diabetes, monotherapy, and combination therapy for diabetes, Vernonia species, Vernonia amydalina, phytochemicals of $V$. amydalina, the anti-diabetic effect of $V$. amydalina. A total of 150 published articles were studied, and 85 articles were used for this review. About $6 \%$ of the published articles used for the present study have digital object identifiers (DOI).

\section{Results and Discussion}

\subsection{Diabetes.}

Diabetes mellitus is listed among the top 10 causes of death in adults, and it is estimated to cause millions of deaths globally every year. According to the International Diabetes Federation (IDF), there were estimated record of 425 million people who had diabetes (Type 1 diabetes, T1D and Type 2 Diabetes, T2D combined) in 2017, and in the same year, the global health expenditure on diabetes was estimated to be USD 727 billion [4].

Diabetes mellitus is a metabolic disorder associated with high blood sugar levels, where one's body cannot effectively control glucose metabolism. A major source of energy for the cell is glucose. For the glucose to enter the cells, it requires insulin produced from the endocrine pancreas. The blood glucose level becomes elevated if the pancreas is unable to produce sufficient insulin, or its activity of promoting glucose uptake is resisted by the cells. Hyperglycemia, increased $\beta$ adrenergic stimulation, and intestinal hormone secretin affects insulin release $[1,5]$. Changes in the activities of defining proteins or enzymes of glucose metabolism or transport in target tissues - liver, muscle, and adipose lead to alterations in the metabolism of the energy molecules. The complications of diabetes are not only limited to chronic metabolic disorders, including alterations in the metabolism of major energy molecules such as carbohydrates, fats, and proteins. Important checkpoints are constituted by the key proteins and/or enzymes in endogenous and exogenous glucose homeostasis. Thus, their mechanism can be exploited in the study of conventional and potential anti-diabetic drugs [6]. 
In its advanced stages, diabetes mellitus affects other metabolic pathways of lipids leading to hypercholesterolemia and hyperlipidemia, which are risk factors in atherosclerosis. Diabetes affects the other vital organs in the body, such as the eyes, liver, and kidneys and the degree of organ involvement depends on the duration and severity of the disease. This leads to retinopathy with a potential vision loss, increased gluconeogenesis, ketogenesis, diabetic ketoacidosis, non-ketotic syndrome, polyuria, and nephropathy leading to renal failure $[5,7]$. Many secondary complications associated with diabetes, such as impaired wound healing, inflammation, foot ulcer, nerve disorders, and sexual depression, are caused by an increase in the concentration of advanced glycation end products (AGEs). Patients with diabetes have a higher chance of getting atherosclerotic cardiovascular, peripheral arterial, and cerebrovascular disease. Hypertension and abnormalities of lipoprotein metabolism are commonly found in people with diabetes $[5,8,9]$.

\subsubsection{Classification of diabetes.}

Diabetes can be classified into two main types; Type-1 Diabetes (T1D) and Type-2 Diabetes (T2D). T1D requires one to be injected with insulin due to the body's failure to produce insulin. This can be caused due to an autoimmune response by the body where the immune system mistakenly attacks and kills the pancreatic beta cells. Serological evidence of an autoimmune pathologic process occurring in the pancreatic islets and by genetic markers can be used to identify the possibility that individuals are at increased risk of developing this type of diabetes. T1D accounts for about $5-10 \%$ of those with diabetes [5,8]. While the other $\sim 90-95 \%$ of the diabetic patients are diagnosed with Type-2 Diabetes, also referred to as noninsulin-dependent diabetes or adult-onset diabetes. T2D is a condition where the availability of insulin in the body leads to a state of fasting hyperglycemia due to the cells becoming insensitive/resistant to the action of insulin. The deficient or diminished effectiveness of endogenously synthesized insulin causes the increase of glucose concentration in the blood and urine. For a long period, pathologic and functional changes in various target tissues can occur with a slight degree of hyperglycemia; however, diabetes won't be detected without clinical symptoms. This is because the hyperglycemia gradually over the years, and it is often not severe in the earlier stages for the patient to notice any symptoms. Many of the patients diagnosed with type-2 diabetes are at risk of developing macrovascular and microvascular complications. T2D patients do not require insulin treatment to survive, and there are many different causes for this type of diabetes. The specific etiologies are unknown; however, autoimmune destruction of pancreatic $\beta$ - cells does not occur. Many patients with this type of diabetes are obese, and some degree of insulin resistance is caused by obesity. Even if the patients are not obese by the traditional weight criteria, they may have a high body fat percentage, mainly in the abdominal region $[5,8,10]$.

As per the Expert Committee on Diagnosis and Classification of Diabetes Mellitus, individuals whose glucose levels are higher than those considered normal but do not meet the criteria for diabetes are defined as having impaired fasting glucose or IFG. A patient is to be considered as IFG if the fasting plasma glucose (FPG) level ranges from $100 \mathrm{mg} / \mathrm{dL}$ (5.6 $\mathrm{mmol} / \mathrm{L})$ to $125 \mathrm{mg} / \mathrm{dL}(6.9 \mathrm{mmol} / \mathrm{L})$, while those with $140 \mathrm{mg} / \mathrm{dL}(7.75 \mathrm{mmol} / \mathrm{L})$ to $250 \mathrm{mg} / \mathrm{L}$ $(11.1 \mathrm{mmol} / \mathrm{L})$ in a 2 - hour postprandial plasma glucose (PPG) test are said to have impaired glucose tolerance or IGT. An individual is considered to have prediabetes, associated with an increased risk of developing T2D in the future if they are IFG and/or IGT. Both IFG and IGT should be considered as risk factors for future development of diabetes ad well as 
cardiovascular diseases. A fasting plasma glucose reading above $126 \mathrm{mg} / \mathrm{dL}(7.0 \mathrm{mmol} / \mathrm{L})$ suggests diabetes mellitus $[1,8]$.

\subsubsection{Treatments of diabetes.}

To date, there is no drug that can cure diabetes completely [9]. Therefore, T1D patients are required to take insulin for life to control blood glucose levels. Ingestion of high-calorie foods, family history of the disease, obesity, race, genetic disorders, smoking, inactivity, viral infections, and drug or chemicals are all associated with Type-2 Diabetes and can be managed with pharmacological and/or non-pharmacological means. The pharmacological means are drugs/ oral hypoglycemic, while non-pharmacological means are diet and exercise $[3,5]$.

Many individuals diagnosed with T2D can achieve their target blood sugar levels with interventions in their lifestyle alone; however, some may require medication to manage their glucose levels. These medical treatments can manage the blood glucose levels by either activating chemicals that enhance insulin secretion or suppressing hepatic glucose output. The decision on the medication depends on many factors, including the individual's blood sugar level and any other health problems they may have. There is also the possibility of combining drugs from different classes to help control glucose levels. Specific organs or metabolic pathways are targeted by most of the conventional and herbal treatments designed for diabetes. Table 1 illustrates the organs targeted by both conventional and herbal drugs in general for diabetes management in patients $[5,11,12]$.

\subsubsection{Pharmacotherapy.}

All anti-diabetic drugs, except for insulin, are considered pharmacological agents that have the ability to treat hyperglycemia in type 2 diabetes mellitus. Pharmacological treatment with drugs is administered when lifestyle modifications such as weight loss, dietary modification, and exercise do not reduce blood glucose levels [13]. The therapeutic treatment begins with monotherapy and progresses to dual therapy or multi-agent therapy followed by insulin administration in combination with other anti-diabetic drugs. Due to the increase in demand for anti-diabetic drugs, there are regularly new drugs in the market [14]. The orally diagnosed anti-diabetic medications consist of many classes of drugs, including biguanides, sulfonylureas, meglitinide, thiazolidinedione (TZD), dipeptidyl peptidase 4 (DPP-4) inhibitors, sodium-glucose cotransporter (SGLT2) inhibitors, and $\alpha$-glucosidase inhibitors.

Combination therapy with two oral reagents or insulin is considered when the hemoglobin $\mathrm{A} 1 \mathrm{C}$ level rises to $7.5 \%$ while on medication or if the initial $\mathrm{HbA} 1 \mathrm{C}$ is $\geq 9 \%$. These medicines are applicable to be used by all patients; however, before usage, some factors should be considered, such as the drug's ability to reduce blood sugar levels, its effect on body weight, any side effects, its reaction to other drugs, and the price $[15,16]$.

Table 1. Therapeutic targets for the management of diabetes mellitus [5].

\begin{tabular}{l|c} 
Therapeutic Target & Functions \\
\hline \multirow{3}{*}{ Adipose Tissue } & $\bullet$ Adipocyte function \\
& $\bullet$ Adipocyte differentiation \\
& $\bullet$ Glucose uptake \\
\hline \multirow{3}{*}{ Intestine } & $\bullet$ Oxidative Stress \\
& $\bullet \alpha$ - amylase inhibitors \\
& $\bullet \quad \beta$ - glucosidase inhibitors \\
& $\bullet \quad$ DPP-IV inhibitors
\end{tabular}




\begin{tabular}{|c|c|}
\hline Therapeutic Target & Functions \\
\hline Liver & $\begin{array}{ll}\text { - } & \text { Hepatic glucose metabolism } \\
\text { - } & \text { Glucose utilization } \\
\text { - } & \text { Gluconeogenesis } \\
\text { - } & \text { Lipotoxicity }\end{array}$ \\
\hline Muscle & $\begin{array}{ll}\text { - } & \text { Myocyte function } \\
\text { - } & \text { Glucose uptake } \\
\text { - } & \text { Lipotoxcity } \\
\text { - } & \text { Oxidative stress } \\
\end{array}$ \\
\hline Pancreas & $\begin{array}{ll}\text { - } & \beta \text { - cell function } \\
\text { - } & \text { Insulin secretion } \\
\text { - } & \beta \text { - cell proliferation } \\
\text { - } & \text { Oxidative stress }\end{array}$ \\
\hline
\end{tabular}

The most commonly used drug in diabetic treatments is metformin. It has a beneficial effect on glucose metabolism and also aids in weight loss or weight stabilization. Based on numerous studies, it was found that metformin reduced mortality and the risk of complications. For a certain patient, if metformin is not tolerated and does not control the blood glucose levels as expected, they should be administered another class of anti-diabetic medicine [13]. Even though the safety of anti-diabetic drugs is assured, they have multiple modes of action and have unknown effects throughout the body [14]. Many anti-diabetic drugs are not recommended, or patients with moderate or severe renal failure or any other significant comorbidities should be instructed to use them with caution. During pregnancy or breastfeeding, the use of oral antidiabetic drugs is prohibited [13].

The classes of anti-diabetic medications (oral) that are currently in use were analyzed with the help of literature (Table 2). Biguanide and its derivatives were discovered in the middle ages and were introduced in the 1920s [14, 16]. This was by discovering Galega officinalis, a herb that has blood glucose reducing capabilities and was found to contain guanidine, galegine, and biguanide [16]. Until the 1950s, these agents were forgotten, which was when biguanides were re-investigated for diabetes treatment. Three biguanides were reported for anti-diabetic action by the late 1950s: phenformin, buformin, and metformin. In many countries, both phenformin and buformin were discontinued due to a high incidence of lactic acidosis. Thus, the only biguanide currently on the market is metformin, the go-to medicine for diabetes patients [14]. Metformin reduces blood glucose levels by activating the adenosine monophosphate-activated protein kinase in the liver. The complex effect on the mitochondrial enzymes causes hepatic glucose uptake and inhibits glucose gluconeogenesis [16]. It is known to slow down the progress of type-2 diabetes in patients. It is also known to have only mild side effects such as the risk of hypoglycemia, reduced vitamin B12 absorption, gastrointestinal complaints (e.g., diarrhea, abdominal cramps), and low chances of weight gain $[13,16]$.

Sulfonylureas became the first pharmacological option in treating non-insulindependent diabetes by 1955. The first generation of sulfonylureas was: tolbutamide, chlorpropamide, acetohexamide, and tolazamide which were replaced by the second generation. The newer agents include glimepiride, gliclazide, glipizide, and glibenclamide (glyburide) [14]. Sulfonylureas control blood glucose levels by stimulating insulin production in the pancreas and improving the efficacy of insulin in the body. Usually, sulfonylureas are not recommended for overweight or obese patients due to weight gain [17]. Other side effects include the risk of hypoglycemia, hematological changes such as agranulocytosis, hemolysis [13]. Meglitinides are another class of anti-diabetic drugs. They act similar to sulfonylureas by increasing the insulin secretion from the pancreatic $\beta$ - cells. However, unlike sulfonylureas, they are associated with a low risk of developing hypoglycemia [13]. Until present, there have 
been three meglitinides used in clinical practice: nateglinide, repaglinide, and mitiglinide [14]. The side effects are also similar to sulfonylureas, such as weight gain, risk of hypoglycemia, and liver failure [13].

Fixed-dose combination therapy (FDC) is common in anti-diabetic management since monotherapy does not provide an acceptable permanent benefit or glycaemic control in many patients. Moreover, concurrent use of several anti-diabetic medications results in poor treatment adherence. FDC products for diabetic management improve patient compliance, reduce the frequency of drug administration, reduce risk of events and provide the synergistic effect as compared to administration of two drugs independently [18]. For most patients with type 2 diabetes, the most prevalent multiple drug therapy is a combination of metformin and sulfonylurea, followed by thiazolidinediones or $\alpha$-glucosidase inhibitors [19, 20]. Sulfonylurea acts upon the insulin released from the beta cells of the pancreas, and metformin acts by improving the insulin sensitivity of muscle and liver, whereas pioglitazone improves adipose tissue insulin sensitivity. Voglibose is an $\alpha$-glucosidase inhibitor that acts by reducing the postprandial blood glucose by regulating glucose absorption. For FDC, currently, in the market, there are an array of commercial pharmaceutical tablets available. These combined metformin and sulfonylurea medications ate available under several brands (Table 3) [18].

FDC of glibenclamide and metformin improved HBA1c levels in diabetic patients who swapped from monotherapy to dual anti-diabetic therapy [9].

Table 2. Overview of orally administered anti-diabetic drugs.

\begin{tabular}{|c|c|c|c|}
\hline Class & Selected drugs (Brand name) & Mechanism of action & Reference \\
\hline Biguanide & Metformin (Glucophage) & $\begin{array}{l}\text { Decreases blood glucose levels by decreasing hepatic } \\
\text { glucose production (gluconeogenesis), and increasing } \\
\text { insulin sensitivity by increasing peripheral glucose uptake } \\
\text { and utilization. }\end{array}$ & {$[13,16]$} \\
\hline Sulfonylureas & $\begin{array}{l}\text { First-generation: } \\
\text { Chlorpropamide } \\
\text { Tolazamide } \\
\text { Tolbutamide } \\
\text { Second-generation: } \\
\text { Glyburide (Diabeta, Micronase) } \\
\text { Glimepiride (Amaryl) } \\
\text { Glipizide } \\
\text { Gliclazide }\end{array}$ & $\begin{array}{l}\text { Increase insulin secretion from the liver } \\
\text { through the stimulation of pancreatic beta cells. }\end{array}$ & {$[21]$} \\
\hline Meglitinides & $\begin{array}{l}\text { Nateglinide (Starlix) } \\
\text { Repaglinide (Prandin) } \\
\end{array}$ & $\begin{array}{l}\text { Increase insulin secretion by regulating ATP-sensitive } \\
\text { potassium channels in pancreatic beta cells. }\end{array}$ & {$[22]$} \\
\hline $\begin{array}{l}\text { Gliptins or Dipeptidyl } \\
\text { peptidase } 4 \text { (DPP-IV) } \\
\text { inhibitor }\end{array}$ & $\begin{array}{l}\text { Alogliptin } \\
\text { Anagliptin } \\
\text { Linagliptin } \\
\text { Saxagliptin } \\
\text { Sitagliptin } \\
\text { Teneligliptin } \\
\text { Vildagliptin } \\
\end{array}$ & $\begin{array}{l}\text { Prevent degradation of GLIP }-1 \text {. } \\
\text { Increase insulin secretion, with an increase in blood sugar. } \\
\text { Suppress glucagon production in response to a } \\
\text { carbohydrate-containing meal. } \\
\text { Decrease the risk of } \\
\text { hyperglycemia and weight gain. }\end{array}$ & {$[13,14,16]$} \\
\hline $\begin{array}{l}\text { Sodium-glucose } \\
\text { cotransporter (SGLT-2) } \\
\text { inhibitor (canagliflozin, } \\
\text { dapagliflozin, } \\
\text { empaglifozin) }\end{array}$ & $\begin{array}{l}\text { Canagli iozin, } \\
\text { Dapagliflozin (Daploz, daplozmet) } \\
\text { Empaglifozin (Jardiance) } \\
\text { Ertuglifozin. }\end{array}$ & $\begin{array}{l}\text { By inhibiting SGLT-2 in the kidney, glucosuria is } \\
\text { increased } \\
\text { Block glucose reabsorption by the kidneys resulting in } \\
\text { increased urinary excretion of glucose. }\end{array}$ & {$[13,16]$} \\
\hline Thiazolidinediones & $\begin{array}{l}\text { Pioglitazone (Actos) } \\
\text { Rosiglitazone (Avandia) }\end{array}$ & $\begin{array}{l}\text { Improve pancreatic } \beta \text {-cell function and insulin sensitivity. } \\
\text { Increase glucose uptake by skeletal muscle }\end{array}$ & {$[13,16]$} \\
\hline $\begin{array}{l}\text { Alpha-glucosidase } \\
\text { inhibitors }\end{array}$ & $\begin{array}{l}\text { Acarbose } \\
\text { Miglitol (Glyset) } \\
\text { Voglibose (Starvog) }\end{array}$ & $\begin{array}{l}\text { Inhibition of carbohydrate absorption in the } \\
\text { gastrointestinal tract (small intestine) }\end{array}$ & {$[21]$} \\
\hline
\end{tabular}

Table 3. Fixed-dose commercial pharmaceutical tablets of metformin [18].

\begin{tabular}{l|l} 
Brand Name & $\begin{array}{l}\text { Drug combination } \\
\text { (composition of Tablet) }\end{array}$ \\
\hline Glucovance & Glibenclamide/ Metformin, 2.5mg/500 mg
\end{tabular}




\begin{tabular}{l|l} 
Brand Name & $\begin{array}{l}\text { Drug combination } \\
\text { (composition of Tablet) }\end{array}$ \\
\hline Metaglip & Glipizide/ Metformin \\
\hline Diapred-m2 & Glimipiride/ Metformin \\
\hline Jardiance Duo & Empagliflozin/ Metformin, $12.5 \mathrm{mg} / 500 \mathrm{mg}$ \\
\hline Trajenta Duo & Linagliptin/Metformin, $2.5 \mathrm{mg} / 500 \mathrm{mg}$ \\
\hline Istamet & Sitagliptin/metfomin \\
\hline Pioglu & Pioglitazone/metformin \\
\hline Volix & Voglibose/metformin
\end{tabular}

\subsubsection{Herbal treatment.}

In recent years, the use of herbal products for preventive and therapeutic purposes has been increasing among the population. This is mostly due to the belief that 'natural' implies safety. Many patients with diabetes use natural herbs alone or alongside the prescribed drugs in disease management. This is noted mainly in severe cases of type-2 diabetes patients. This might be the difficulty in attaining adequate glycemic control despite the pharmacotherapy present because of the decline in $\beta$ - cell function. Leading to long treatment plans, making patients seek out alternative forms of treatment [23]. Since the use of herbal medicine in diabetes treatment is becoming widespread, a study was conducted by Ezuruike et al., 2016, where the potential herb-drug interaction among Nigerian diabetic patients was assessed. This literature analysis was done based on 112 patients with type-2 diabetes, and fifty percent of the participant's used herbs alongside their prescription drugs. A large number $(60 \%)$ of the patients did not know the type of herbs they were using, whereas the most prominently used plant was VA followed by Ocimum gratissimum L. and Musa paradisiaca. It was concluded due to the lack of clinical predictors that the influence for herb use was due to cultural factors [23].

Improvement of glucose and lipids by using cinnamon in people with type-2 diabetes was determined by Khan et al., 2003. In the study, 60 people with type-2 diabetes were randomly given cinnamon or placebo, daily for 40-days, followed by a 20-day washout period. It was found in the results that cinnamon reduced serum glucose, triglyceride, LDL, and total cholesterol in patients with type-2 diabetes [24]. In 2016, a study was conducted by Attanayake et al., using Coccinia grandis (Linn.) Voigt (Cucurbitaceae) leaf extract. It investigated the antihyperlipidemic, antioxidative effect of leaf extract in streptozotocin induced diabetic rats and standardized the leaf extracts by a standard analytical method. There was significant improvement $(P<0.05)$ in total cholesterol, triglycerides, and antioxidation potential. It was proven that $C$. grandis leaf extract possesses the ability to manage diabetic complications [25].

A study was conducted using different doses of cyclohexane and ethanol extracts of walnut leaf on diabetic male rats. The increased activity of aldose reductase (AR) was targeted in order to study the prevention of diabetes complications. The AR activity in the lens and testis of diabetic rats was analyzed in this study. Compared to the control group, the AR activity in both the extracts reduced significantly $(P<0.05)$. Thus, it was concluded by the study that walnut leaf extract can reduce the activity of AR. However, further studies are required to establish its effect on other species or humans [26]. A systematic review of the published literature on the efficacy and safety of 36 herbal therapies (single or combination) and 9 dietary supplements for glycaemic control in 4,565 patients with diabetes or impaired glucose tolerance was reported by Yeh et al., 2003. It was concluded in the study that there was insufficient evidence on the herbs and supplements to draw a definite conclusion. However, they were found to be generally safe [27]. A review of medicinal potentials of plants of the 
genus Vernonia based on results from a combination of in vitro and in vivo efficacy and toxicity studies reported showed that Vernonia amygdalina is the most promising species for development into a nutraceutical against diabetes [28].

\subsection{Vernonia amygdalina.}

The Vernonia genus has about one thousand species, and members are widely used as food and medicine. VA is scientifically classified into the kingdom Plantae that is an angiosperm of the order Asterales. VA belongs to the Asteraceae family and genus Vernonia. The Asteraceae family consists of herbs, shrubs, or, less commonly, trees. They are considered the largest family of flowering plants with approximately 1620 genera and about 23,600 species [29]. Vernonia species can easily adapt to their habitat according to different environments. In forests, they can be found next to water sources but also in forest margins, woodlands, grasslands up to $2800 \mathrm{~m}$ in altitude, and a mean annual rainfall of 750-2000 $\mathrm{mm}$ [30]. Vernonia is the largest genus with approximately 1000 species of shrubs, out of which VA is the most prominent $[29,31]$.

VA is usually cultivated by stem planting, and it doesn't produce seeds [31]. VA is a perennial soft wooded shrub with a height of about 2 to $10 \mathrm{~m}$ with stem diameter up to $40 \mathrm{~cm}$. The shrub's bark is densely pubescent at the early stage; when the plant gets matured, the bark turns from grey to brown. The leaves are petiolate in shape arranged alternatively to each other [30, 31]. Flowers of VA are regular and bisexual, and then they develop into fruits. The fruits are shaped into 10-ribbed achene lengths up to $1.5-3.5 \mathrm{~mm}$ [30]. The most frequently used member of the Vernonia genus is Vernonia amygdalina (VA). VA is commonly known as a bitter leaf due to the bitter taste of the leaves. The shrub is commonly found in tropical Africa, where it is domesticated. It can also be found in some regions of Asia, including Malaysia. VA is consumed as a green leafy vegetable throughout West and Central Africa as a source of due for its nutritional and medicinal properties [28].

\subsubsection{Pharmacological effects/ethnopharmacological activity.}

Extracts of VA have been used traditionally as a tonic and in treating sexually transmitted diseases, feverish conditions, cough, constipation, and hypertension. Traditionally, in different parts of Africa, VA is used as a remedy for many medical purposes. A decoction of its roots and leaves is used in ethnomedicine to treat fevers, hiccups, kidney problems, and stomach discomforts, among others [29]. In Nigeria, a tonic is made from the plant for medicinal purposes. The bitter taste is removed by boiling the leaves and then using them as a soup condiment.

Similarly, a popular Nigerian dish known as 'Onugbo' is made [30]. It is also used in the treatment of diabetes, diarrhea, dysentery hepatitis, and cough. In addition, the leaves are used against nematodes in humans [29].

The pharmacological properties of VA have been studied to validate its therapeutic effects VA is identified as the most medically beneficial plant in the genus Vernonia. VA possesses several activities, including anti-diabetic, anti-plasmodial, cathartic, antioxidant, antimicrobial, hypolipidemic [2, 28, 29, 30, 32].

The antioxidant property of crude VA extracts was studied for years. Aqueous extracts of VA leaf showed a decrease in serum malondialdehyde levels in streptozotocin-induced diabetic rats that underwent oxidative stress [32]. In research for evaluation of phytochemicals, 
proximate and antioxidant composition in conjunction with its effect in vivo on diabetes and obesity biomarkers, antioxidant and hematological profiles. This study carried out by Imaga and Bamigbetan [33] increases the level of the antioxidants, glutathione (GSH), superoxide dismutase (SOD), catalase, and malondialdehyde (MDA) of the test rats as compared to control, which is shown in the in-vivo antioxidant. The injection of VL into the rat's system leads to improvement in the functionality of the antioxidant system, possibly due to the effect of the phytochemical antioxidants in the extract.

The ethanol extract of VL can suppress parasitemia very easily during the early stages of injection. Sesquiterpene lactones are responsible for anti-malarial activity. In the same study by Audu et al., the anticancer properties of VA leaves were studied. The exposure of BT-549 to three different VA volumes $(10,100$, and $1000 \mu \mathrm{g} / \mathrm{mL})$ led to cell growth by approximately $14 \%, 22 \%$, and $50 \%$ in order [35]. A study was done to assess the anticancer effects of VA leaves fractions on 4T1 breast cancer cells. The Ethylacetate fraction (EAF) of VA leaves contains many bioactivity compounds capable of performing anticancer activity in the 4T1 cancer cells [34].

The lipid-lowering effects of ethanolic leaf extract of VA on high cholesterol diet rats were conducted by Adaramoye et al. The values for total cholesterol, triglyceride, low-density lipoprotein (LDL) cholesterol, high-density lipoprotein (HDL) cholesterol, lipid peroxidation (LPO), phospholipid, and glutathione (GSH) were all measured for the plasma and liver of the rats. There was a significant $(P<0.05)$ decrease in the cholesterol levels indicating the new potential of VA for hyperlipidemia treatment [36]. The effect of aqueous VA leaves on hypoglycemic and hypolipidemic were analyzed using alloxan-induced diabetic rats. In the duration of two weeks, rats were treated with different concentrations of VA extract. In the end, there was a significant $(P<0.05)$ decrease in the fasting glucose level respective of the alloxan-induced diabetic levels [2].

\subsubsection{Toxicology.}

There have been studies conducted on mice for the toxicology of VA. These studies showed no clinical signs of toxicity or toxicological effects in the treated animal groups. The only signs are of decrease in red blood cell count and an increase in serum bilirubin as per dosage [31]. Lower doses of ethanolic leaf extract, around $100 \mathrm{mg} / \mathrm{kg}$ per oral, show no effects in male albino rats' testis. However, higher dosages $(300-600 \mathrm{mg} / \mathrm{kg}$ ) per oral shows toxicity [29]. In the paper by Adefisayo et al., oral toxicity was done regarding the effect of methanol VL extract on aspirin-induced gastric ulcers in Wistar rats. In the study, it was found that methanolic extract up to $3400 \mathrm{mg} / \mathrm{kg}$ didn't cause any toxicity. Thus, it can be said that VA causes no clinical signs of toxicity or toxicological effects when given in amounts [37]. VA has been reported to be safe and considered as a lead herbal drug candidate with good efficacy, fewer side effects, and reduced toxicity for clinical trials [38].

3.2.3. Anti-diabetic properties/ the use of VA in the management of diabetes.

Vernonia amygdalina (VA) is cultivated in tropical African and Southeast Asia countries, and the leaves are consumed as a vegetable in the traditional management of diabetes. Diabetes patients use pulverized fresh leaves that are soaked in water and are taken orally. In addition, the leaf extract of VA has been explored as an alternative therapeutic and preventive option in managing diabetes in many studies. Numerous research studies 
demonstrated that VA leaves can be developed as an effective and safe drug for diabetes management due to their anti-diabetic properties [39]. Studies to investigate the hypoglycemic properties of Vernonia amygdalina Del. (VA) and its possible mechanisms of action in streptozotocin-induced diabetic rat models have been conducted.

Ong et al. conducted a dose-response study to determine the optimum dose for the hypoglycemic effect of VA in STZ-induced diabetic rats. The optimum dose $(400 \mathrm{mg} / \mathrm{kg}$ ) was used throughout the 28-day chronic study. The ethanolic extract of VA showed a significant improvement in glucose tolerance of the STZ-induced diabetic rats [40]. A similar study of anti-diabetic properties of different extracts of VA showed that the chloroform extract has the highest blood and serum glucose-lowering effects compared to methanol and petroleum ether extracts [41]. The effect of methanol crude VA extract on streptozotocin treated rats of type-2 diabetes was carried out by Okoduwa et al. to validate the anti-diabetic effects of fractions of methanolic leaf extracts of VA. The methanol crude extract was fractionated with $n$-hexane, chloroform, ethyl-acetate, $n$-butanol, and water. After a 28 -day post oral treatment of the diabetic rats with the fractions, the results showed a significant decrease in the fasting blood glucose levels $(P<0.05)$. The diabetic rats treated with chloroform fraction showed the maximum glucose tolerance with a fasting blood glucose reduction of $66.7 \%$ [39]. The effect of VA (methanolic extract) capsules with a combination of anti-diabetic drugs glibenclamide or metformin was studied in male streptozotocin-induced diabetic rats has been reported [3]. The aqueous leaf extract of VA is also reported to exhibit a reduction in blood glucose in fasted normal and alloxanized rabbits. The effect was comparable with those of tolbutamide and chlorpropamide, which are standard drugs used in the management of diabetes, and it also improves the repair of the pancreas [42].

Studies to investigate the anti-diabetic mechanism of action of VA have been reported. Atangwho et al. studied the anti-diabetic mechanism of VA leaves and its impact on the transcription of key enzymes involved in cellular modulation of glucose in streptozotocininduced diabetic rats for a period of 14 days. After an administration period of $200 \mathrm{mg} / \mathrm{kg}, 400$ $\mathrm{mg} / \mathrm{kg}$, and metformin, the results showed a significant decrease in diabetic levels. However, it was suggested by the study that there was little or no effect on glycolysis. Instead, the VA achieves its anti-diabetic effect by simultaneously suppressing gluconeogenesis and potentiating glucose oxidation through the pentose phosphate pathway [6]. Another study on the RNA content of the pancreas of the diabetic animal model to elucidate the possible mechanism of action of VA was conducted by Asanga et al. The results showed the aqueous extract caused an increase in the cell mass of the pancreas, enhanced proliferation of the $\beta$-cells of islets of Langerhans of the pancreas as evidenced in the RNA content of the postmitochondrial supernatant and whole homogenate obtained by the fractionation of the pancreas [43].

The anti-diabetic effect of the combination of metformin $(50 \mathrm{mg} / \mathrm{kg})$ and aqueous extracts of VA leaf $(100 \mathrm{mg} / \mathrm{kg})$ indicated that the combination of the aqueous leaf extract and metformin was efficacious, additive, and safe for the management of diabetes mellitus [44]. The blood sugar lowering effect of VA leaf has been confirmed by several published studies. Table 4 summarizes the literature reports of the anti-diabetic effect of VA. Each of the published articles mentioned in this review highlights the benefits of the leaf of VA in managing diabetes and other blood sugar-related conditions.

The proximate components present includeproteins, ash, carbohydrates, minerals, and crude fiberamong others. Bioactive compositions include Stigmastane-type saponins, 
flavonoids, sesquiterpene lactones, and others such as terpenes, coumarins, phenolic acids, etc. Many studies have been conducted for the identification of bioactive compounds in VA by isolating and characterizing them. The phytochemical studies show many phytochemicals such as saponins, flavonoids, alkaloids, tannins, and several types of sesquiterpene lactones [30, 31, 45-47]. Some of the isolated bioactive compounds from VA leaves that are reported in the literature are shown in Table 5.

The bioactive compounds composition for VA leaves was found to be flavonoids $(0.85 \%)$, tannins $(0.37 \%)$, saponins $(2.2 \%)$, polyphenols $(0.35 \%)$, alkaloids $(2.13 \%)$, and $\mathrm{HCN}$ $(12.25 \%)$ in a study by Nwaoguikpe et al., where the effect of bitter leaf extract on blood glucose levels of diabetic rats was studied [48]. Similar amounts of bioactive were found by Atangwho et al. when a comparative study on the composition of leaves from anti-diabetic plants; Azadirachta indica, Vernonia amygdalina, and Gongronema latifolium was done. VA leaves had the highest content of flavonoids, saponins, and polyphenols among the three plants used [49]. The content of bioactive components in VA according to Ezekiel et al., was tannin (3.34 mg/100g), phenol (1.78 mg/100g), phytate (19.69 mg/200g), Oxalate $(3.78 \mathrm{mg} / 100 \mathrm{~g})$, Saponin $(3.76 \mathrm{mg} / 100 \mathrm{~g})$, Alkaloids $(3.59 \mathrm{mg} / 100 \mathrm{~g})$ and flavonoids $(4.09 \mathrm{mg} / 100 \mathrm{~g})$ [50]. The presence of oxalates, phytates, and tannins was also found in reports by Kadiri and Olawoye, Zakaria et al., and Adefisayo et al. [37, 46, 47]. The bitterness present in the VA leaves is due to the presence of the A - series saponins, alkaloids, tannins, and glycosides [20, 45]. Sesquiterpene lactones are another bioactive compound found abundantly in VA leaves (Table 5). Primary screening of ethanolic extract of old and young VL leaves showed the presence of alkaloids, saponins, tannins, glycosides, and terpenoids. However, flavonoids were absent in the young leaf extract and only present in the old leaves [10].

Table 4. Studies on anti-diabetic effects of VA in alloxan or streptozotocin-induced Type II diabetic rat model.

\begin{tabular}{|c|c|c|c|}
\hline S. No & Extract & Outcomes $^{\mathbf{a}}$ & References \\
\hline 1. & Aqueous & Hypoglycemic effect & {$[1]$} \\
\hline 2. & Aqueous & Hypoglycemic and hypolipidemic effect & [32] \\
\hline 3. & Aqueous & Hypoglycemic and hypolipidemic effect & [51] \\
\hline 4. & Aqueous & $\begin{array}{l}\text { Anti-diabetic effect } \\
\text { Increase in the cell mass of the pancreas. } \\
\text { Enhance proliferation of the } \beta \text {-cells of islets of Langerhans of } \\
\text { the pancreas. }\end{array}$ & [43] \\
\hline 5. & Aqueous & Hypoglycemic effect & {$[52]$} \\
\hline 6. & Aqueous & Hypoglycemic and hypolipidemic effect & [53] \\
\hline 7. & Chloroform & $\begin{array}{l}\text { Anti-diabetic effect } \\
\text { Suppression of gluconeogenesis and potentiation of glucose } \\
\text { oxidation via PPP pathway in the liver }\end{array}$ & [6] \\
\hline 8. & Ethanol & Hypoglycemic and hypolipidemic effect & [54] \\
\hline 9. & Ethanol & Hypoglycemic and hypolipidemic effect & [10] \\
\hline 10. & Ethanol & $\begin{array}{l}\text { Hypoglycemic and hypolipidemic effect } \\
\text { The protective effect over pancreatic } \beta \text {-cells } \\
\text { Increase in insulin level. } \\
\text { Stimulation of skeletal muscle's glucose uptake } \\
\text { Restoration in skeletal muscle glycogenesis }\end{array}$ & [40] \\
\hline 11. & Ethanol & $\begin{array}{l}\text { Hypoglycemic effect } \\
\text { Reduction in serum urea, chloride, and sodium concentrations } \\
\text { Elevation of serum potassium and creatinine concentrations }\end{array}$ & {$[55]$} \\
\hline 12. & Ethanol & Hypoglycemic effect & [56] \\
\hline 13. & $\begin{array}{l}80 \% \\
\text { methanol }\end{array}$ & Hypoglycemic effect & [39] \\
\hline 14. & $\begin{array}{l}80 \% \\
\text { methanol }\end{array}$ & Hypoglycemic effect & [3] \\
\hline 15. & $\begin{array}{l}70 \% \\
\text { methanol }\end{array}$ & Hypoglycemic and hypolipidemic effect & {$[57]$} \\
\hline 16. & Methanol & Hypoglycemic effect & [58] \\
\hline 17. & Methanol & Hypoglycemic and hypolipidemic effect & [59] \\
\hline
\end{tabular}




\begin{tabular}{l|l|l|c} 
S. No & Extract & Outcomes $^{\mathbf{a}}$ & References \\
\hline 18. & Methanol & Hypoglycemic effect and hypolipidemic effect & {$[60]$} \\
\hline 19. & Methanol & Hypoglycemic effect and hypolipidemic effect & {$[61]$} \\
\hline 20. & Methanol & Hypoglycemic & {$[62]$}
\end{tabular}

${ }^{a}$ The results of diabetic animals treated with the extracts (test group) compared to the values of their normal control groups.

\subsubsection{Bioactive constituents.}

Table 5. Major bioactive compounds isolated compounds from Vernonia amygdalina leaf.

\begin{tabular}{|c|c|c|c|}
\hline S. No & Isolated compound & Chemical structure & Reference \\
\hline 1. & Luteolin & & {$[28,45]$} \\
\hline 2. & Luteolin $7-O-\beta$-glucuronide & & {$[28,45]$} \\
\hline 3. & Luteolin 7-O- $\beta$-glucoside & & {$[28,45]$} \\
\hline 4. & Vernonioside A1 & & {$[45,63]$} \\
\hline 5. & Vernonioside A2 & & {$[45,63]$} \\
\hline 6. & Vernonioside A3 & & {$[45,63]$} \\
\hline
\end{tabular}




\begin{tabular}{|c|c|c|c|}
\hline S. No & Isolated compound & Chemical structure & Reference \\
\hline 7. & Vernonioside A4 & & {$[45,63]$} \\
\hline 8. & Vernonioside B1 & & {$[45,64]$} \\
\hline 9. & Vernonioside B2 & & [28] \\
\hline 10. & Vernonioside D & & {$[65]$} \\
\hline 11. & Vernocuminoside $\mathrm{G}$ & & {$[65]$} \\
\hline 12. & Vernolide & & {$[45,64]$} \\
\hline 13. & Vernodalol & & {$[45,64]$} \\
\hline
\end{tabular}




\begin{tabular}{|c|c|c|c|}
\hline S. No & Isolated compound & Chemical structure & Reference \\
\hline 14. & Vernodalinol & & {$[65]$} \\
\hline 15. & Vernomenin & & {$[31]$} \\
\hline 16. & Vernolepin & & {$[45,64]$} \\
\hline 17. & Vernodalin & & {$[45,64]$} \\
\hline 18. & Vernomygdin & & {$[45,66]$} \\
\hline 19. & Epivernodalol & & {$[65]$} \\
\hline 20. & 11,13-dihydrovernodalin & & {$[65]$} \\
\hline 21. & 4,15-dihydrovernodalin & & [31] \\
\hline 22. & Hydroxyvernolide & & [31] \\
\hline
\end{tabular}




\begin{tabular}{|c|c|c|c|}
\hline S. No & Isolated compound & Chemical structure & Reference \\
\hline 23. & $\begin{array}{l}1,2,2^{\prime}, 3^{\prime}- \\
\text { tetrahydrovernodalin }\end{array}$ & & [31] \\
\hline 24. & Thiamin & & [31] \\
\hline 25. & Ascorbic acid & & [31] \\
\hline 26. & Pyridoxine & & [31] \\
\hline 27. & Glycine & & [31] \\
\hline 28. & Cysteine & & [31] \\
\hline 29. & Casein hydrolysate & & [31] \\
\hline 30. & Chlorogenic acid & & [67] \\
\hline 31. & 8-methyloctahydrocoumarin & & [68] \\
\hline
\end{tabular}

Flavonoids are another group of bioactive compounds found in VA leaves. They play an important role in the taste, color, protection of plant vitamins and enzymes and stop fat oxidation. Various flavonoids isolated from VA leaves using organic solvents are most commonly three flavones: luteolin, luteolin 7-O- $\beta$-glucoroniside and luteolin 7-O- $\beta$-glucoside $[31,45]$. From the identified flavones exhibited the strongest oxidant activities comparable to synthetic butylated hydroxytoluene (BHT). The most abundant compound in VA leaves was luteolin 7-O- $\beta$-glucoroniside, and along with luteolin, 7-O- $\beta$-glucoside both possess antioxidant activity (lower compared to luteolin). According to Yeap et al., the most effective method for luteolin extraction was found to be using ethanol [20]. Luteolin has been scientifically established as an antioxidant, anti-inflammatory, anti-estrogenic, antitumorigenic, anti-mutagenic, anti-apoptotic, anti-allergic, and anti-diabetic [69].

The stigmastane-type saponins vernoniosides A1, A2, A3, and B1 were first isolated from VA leaves in 1992 [70]. Later in 1993, three stigmastane-type steroid glucosides, vernonioside A4, B2, and B3 were isolated from VA [71]. It was observed by Ohogashi et al. 
that these saponins had weak antischistosomal, plasmodial, and leishmanicidal activities. However, vernonioside B1 displayed antischistosomal activity [72]. Other stigmastane-type saponins isolated from VA include vernoniosides C, D, and E [73]. Several steroidal saponins such as vernoniamyoside A-D, and vernoamyoside D were found in VA leaves. They demonstrate anti-malaria and antitumor activity, especially anti-breast cancer activity. However, further research on the topics is required [63, 73, 74]. Saponins isolated from VA were also observed to possess antioxidant and hypolipidemic effects [31, 41]. The saponin's content reduces blood glucose levels by reducing oxidative stress and has an anti-diabetic activity to stimulate insulin secretion and action and pancreatic beta-cell regeneration [75].

Terpenoids are another important phytochemical that is responsible for the interaction of plants with their environment. Terpenoids have been shown to have a wide range of biological activities such as antibiotic, cytotoxic, anti-malarial, antifeedant, insecticidal, molluscicidal, and herbicidal properties. Subdivisions of terpenoids include monoterpenes, sesquiterpenes, diterpenes, triterpenes, and carotenoids. In essential oils obtained from the Asteraceae family, including the Vernonia genus, the main constituents are monoterpenes and sesquiterpenes [28]. The pharmacological properties of terpenoids isolated from VA include anticancer, anti-inflammatory, hepatoprotective, antioxidant, antibacterial, antileukemia, analgesic, and anti-nociceptive activities [20, 31, 76]. Some triterpenes isolated from VA are thiamine, ascorbic acid, pyridoxine, glycine, cysteine, casein hydrolysate, eucalyptol, beta piene, myrtenal, and alpha-muurolol (Table 5).

Sesquiterpene lactones are a compound among terpenoids that was found in VA. Some known sesquiterpene lactones include vernolide, vernodalol, vernolepin, vernodalin, vernomygdin, hydroxyvernolide, vernodalinol, vernomenin, and vernolic [29, 45]. They possess pharmacological properties such as antibacterial, anesthetic, antifungal, antiinflammatory, and antimicrobial [31]. These sesquiterpene lactones are also reported to inhibit breast cancer cell growth and possess antitumoral properties.

In 1993, a study was conducted by Jisaka et al., where the antitumoral and antibacterial activities of 10 sesquiterpene lactones were conducted. These studies were carried out in vitro antitumoral activity against mouse leukemia cells, P-388 and L-121O, and the antibacterial activity against Gram-positive bacteria, Bacillus subtilis, and Micrococcus lutea. From the study, it was reported that vernodalin and vernolide exhibit potent antitumor activity while the activity of hydroxyvernolide and vernodalol was weak [77]. In another study vernolide and vernodalol were tested by agar dilution method against 10 bacteria strains (gram-positive and negative) and 5 fungi species. It was found that the two compounds exhibited significant bactericidal activity against 5 Gram-positive bacteria while lacking efficacy against the Gramnegative strains. In the antifungal test, vernolides exhibited high activity ( $\mathrm{LC}_{50}$ values of 0.2 , 0.3 , and $0.4 \mathrm{mg} / \mathrm{ml}$ against Penicillium notatum, Aspergillus flavus, Aspergillus niger, and Mucor hiemalis, respectively). However, vernodalol showed moderate inhibitions against Aspergillus flavus, Penicillium notatum, and Aspergillus niger with $\mathrm{LC}_{50}$ values of $0.3,0.4$, and $0.5 \mathrm{mg} / \mathrm{ml}$, respectively. Both compounds were ineffective against Fusarium oxysporum [78]. Vernolepin also exhibits antiplatelet activity against ADP, arachidonic acid, and collagen-induced platelet aggregation in rabbits [20].

\subsubsection{Nutritional value.}

As a food, vegetable, and culinary herb Vernonia species are grown in many parts of the world. The nutritional content VA has been researched by many researchers. Based on the 
past literature, the presence of protein, carbohydrate, moisture, ash, fiber, and fat in VA is established [46]. A comparative study of chemical compositions of leaves of Azadirachta indica, Vernonia amygdalina, and Gongronema latifolium was carried out in 2009. This study done by Atangwho et al. [49] compared the proximate compositions of the three diabetic plants: crude fiber, ash, fat, and protein. The composition for VA was crude protein $(23.3 \%)$, crude fiber (16.05\%), fat (3.53\%), and ash (10.01\%). When compared with the other two plants, VA had the lowest ash and fat content.

The analyzed crude fiber content by Kadiri and Olawoye is $8.78 \%$ which is the normal amount found in vegetables found in Nigeria [46]. The ash content is $4.28 \%$, which along with the crude fiber, is lesser than the values reported by Asaolu et al. [19]. According to Nwaoguikpe et al., the composition of VA revealed the presence of protein $(62.2 \%)$, crude carbohydrate $(22 \%)$, ash $(9.95 \%)$, crude fiber $(16 \%)$, and crude fat $(3.45 \%)$. The values obtained by Asaolu et al. for crude protein (50.64\%) and ash content (9.56\%) are similar [19, 48]. The nutritional composition of VA, varies from study to study due to different geographical locations, genetic, environmental, harvest conditions, and ecology of the plant used [31]. The ash in the leaves confirms the presence of minerals. Analyses of literature data show that the major minerals present in VA are Potassium (973), Sodium (819), Manganese (710), Calcium (166), and Magnesium (88), while copper, phosphorus, and iron are least detected (Table 6). It should be noted that the old and young age of leaves does have a significant difference in nutrient content [20]. The presence of mineral contents is beneficial in the treatment of diabetes.

Calcium and potassium are beneficial for human health since these two elements play essential roles in many physiological activities, such as the regulation of enzyme activity and blood pressure regulation. Calcium stimulates enzymes in the digestive process and coordinates the functions of all other minerals in the body. Potassium maintains the water-acid balance and in the transmission of nerve impulses to muscle [79]. In controlling the glucose level in the body, potassium and calcium are important as they maintain normal glucose tolerance levels [46].

Magnesium is an important co-factor that is actively involved in metabolic reactions, including carbohydrate metabolism and glycaemic control. Literature report of cross-sectional and longitudinal research indicates that reducing dietary magnesium intake is a risk factor for the incidence of impaired glucose regulation and type 2 diabetes [80]. The benefits and safety of oral magnesium supplementation on glycaemic control in patients with Type 2 diabetes are yet to be ascertained. However, researchers have found that oral magnesium supplementation for 1- 4 months can effectively reduce plasma fasting glucose levels and raise HDL cholesterol in patients with Type 2 diabetes [81].

Manganese is an essential element that plays an important role in various physiological functions. It is important for regulating blood sugar by the metabolism of glucose and insulin secretion [82]. Manganese deficiency is reported to be associated with impaired glucose tolerance and increased risk of metabolic syndrome through impaired glucose and lipid metabolism [83]. Gong et al. examined the association between manganese intake and the risk of type 2 diabetes in postmenopausal women. Their research founding showed that dietary manganese was associated with a lower risk of type 2 diabetes among postmenopausal women. Therefore, consuming food groups rich in manganese could potentially target intervention against type 2 diabetes risk in postmenopausal women [84]. 
The presence of these essential minerals in the leaves of VA highlights the plant's usefulness for managing diabetics.

Table 6. Mineral composition of VA (mg/100g dry weight).

\begin{tabular}{l|c|c|c|c}
\multirow{2}{*}{ Mineral } & \multicolumn{3}{|c}{ Reference } \\
\cline { 2 - 4 } & {$[19]$} & {$[50]$} & {$[46]$} & {$[31]$} \\
\hline Calcium $(\mathrm{mg} / 100 \mathrm{~g})$ & 71.50 & 166.372 & - & 67.39 \\
\hline Sodium $(\mathrm{mg} / 100 \mathrm{~g})$ & 52.76 & 819.469 & 5.0 & 14.48 \\
\hline Iron $(\mathrm{mg} / 100 \mathrm{~g})$ & 16.43 & 6.637 & 85.0 & 8.05 \\
\hline Zinc $(\mathrm{mg} / 100 \mathrm{~g})$ & 18.15 & 3.423 & - & 60.90 \\
\hline Potassium $(\mathrm{mg} / 100 \mathrm{~g})$ & 73.25 & 973.451 & 6.7 & 60.90 \\
\hline Phosphorus $(\mathrm{mg} / 100 \mathrm{~g})$ & 12.52 & - & - & 88.10 \\
\hline Magnesium $(\mathrm{mg} / 100 \mathrm{~g})$ & 61.08 & 19.604 & 710.0 & 5.56 \\
\hline Manganese $(\mathrm{mg} / 100 \mathrm{~g})$ & 3.16 & 0.401 & - & 6.01
\end{tabular}

\section{Conclusions}

In conclusion, diabetes mellitus is a global phenomenon that is spreading around the world rapidly. There are many conventional drugs for diabetes maintenance in the market. However, most of them have some serious side effects or are not suitable for long usage periods. Herbal medicine is a form of healthcare that has been known to humankind for centuries, and in many countries, it is used in diabetes treatment. One such herbal plant is Vernonia amygdalina, a multipurpose plant with many uses, health benefits, and bioactivities. The full potential of this plant for diabetes drug development is still not fully exploited. Thus, this literature review will stimulate further scientific research, possibly discovering novel or lead pharmaceutical agents.

\section{Funding}

The research work was financially supported by UCSI University Research Grant Scheme (Proj-In-FPS-025), awarded by the Centre of Excellence for Research, Value Innovation, and Entrepreneurship (CERVIE), UCSI University.

\section{Acknowledgments}

The authors are thankful to the Faculty of Pharmaceutical Chemistry, UCSI University, Kuala Lumpur, Malaysia, for providing the necessary facilities to search the scientific databases.

\section{Conflicts of Interest}

The authors declare no conflict of interest, financial or otherwise.

\section{References}

1. Adejunwon, S.A.; Osinubi, A.A.; Noronha, C.C.; Okanlawon, A.O. Acute Effect of Vernonia Amygdalina on Blood Glucose Levels in Normoglycaemic and Alloxan-Induced Diabetic Male Sprague-Dawley Rats. West Africa Journal of Anatomy 2005, 8, 161-168.

2. Goje, L.J.; Maisamari, C.; Maigari, F.U.; Ghamba, P.E.; Goji, A.D.T.; Mshelia, P.P. The Hypoglycemic and Hypolipidemeic Effects of the Aqueous Extract of Vernonia Amygdalina Leaves on Alloxan Induced Diabetic Albino Rats. International Journal of Sciences 2014, 3, 1-11.

3. Dorathy, U.N.; Charles, E.O.; Umaru, A.M. Effects of Capsules of Vernonia Amygdalina Combined with Glibenclamide or Metformin on Blood Glucose Levels of Diabetic Rats. International Journal of Pharmaceutical Sciences Review and Research 2017, 44, 9-14.

4. Saeedi, P.; Petersohn, I.; Salpea, P.; Malanda, B.; Karuranga, S.; Unwin, N.; Colagiuri, S.; Guariguata, L.; Motala, A.A.; Ogurtsova, K.; Shaw, J.E.; Bright, D.; Williams, R. Global and Regional Diabetes Prevalence 
Estimates for 2019 and Projections for 2030 and 2045: Results from the International Diabetes Federation Diabetes Atlas, 9th Edition. Diabetes Research and Clinical Practice 2019, 157, 1-10, https://doi.org/10.1016/j.diabres.2019.107843.

5. Odeyemi, S.; Bradley, G. Medicinal Plants Used for the Traditional Management of Diabetes in the Eastern Cape, South Africa: Pharmacology and Toxicology. Molecules 2018, 23, https://doi.org/10.3390/molecules23112759.

6. Atangwho, I.J.; Yin, K.B.; Umar, M.I.; Ahmad, M.; Asmawi, M.Z. Vernonia Amygdalina Simultaneously Suppresses Gluconeogenesis and Potentiates Glucose Oxidation via the Pentose Phosphate Pathway in Streptozotocin-Induced Diabetic Rats. BMC Complementary and Alternative Medicine 2014, 14, 1-13, https://doi.org/10.1186/1472-6882-14-426.

7. Krishnan, B.; Babu, S.; Walker, J.; Walker, B.A.; Pappachan, M.J. Gastrointestinal Complications of Diabetes Mellitus. World Journal of Diabetes 2013, 4, 51-63, https://doi.org/10.4239/wjd.v4.i3.51.

8. American Diabetes Association. Diagnosis and Classification of Diabetes Mellitus. Diabetes Care 2014, 37 , 81-90, https://doi.org/10.2337/dc14-S081.

9. Chandira, M.; Jayakar, B. Formulation and Evaluation of Herbal Tablets Containing Ipomoea Digitata Linn. Extract. International Journal of Pharmaceutical Sciences Review and Research 2010, 3, 101-110.

10. Asante, D.B.; Effah-Yeboah, E.; Barnes, P.; Abban, H.A.; Ameyaw, E.O.; Boampong, J.N.; Ofori, E.G.; Dadzie, J.B. Antidiabetic Effect of Young and Old Ethanolic Leaf Extracts of Vernonia Amygdalina: A Comparative Study. Journal of Diabetes Research 2016, 2016, 1-13, https://doi.org/10.1155/2017/5618548.

11. Ghosal, S.; Ghosal, S. The Side Effects Of Metformin - A Review. Journal of Diabetes \& Metabolic Disorders 2019, 1-14, https://doi.org/10.24966/DMD-201X/100030.

12. Mayo Clinc Type 2 Diabetes Available online: https://www.mayoclinic.org/diseases-conditions/type-2diabetes/diagnosis-treatment/drc-20351199?p=1 (accessed on 9 September 2020).

13. Amboss.com Antidiabetic Drugs Available online: https://www.amboss.com/us/knowledge/Antidiabetic_drugs (accessed on 19 October 2020).

14. Meneses, M.J.; Silva, B.M.; Sousa, M.; Sá, R.; Oliveira, P.F.; Alves, M.G. Antidiabetic Drugs : Mechanisms of Action and Potential Outcomes on Cellular Metabolism. Current Pharmaceutical Design 2015, 21, 36063620, https://doi.org/10.2174/1381612821666150710145753.

15. Anti-diabetic Drugs Available online: https://www.diabetes.co.uk/diabetes-medication/antidiabeticdrugs.html (accessed on 19 October 2020).

16. Chaudhury, A.; Duvoor, C.; Reddy Dendi, V.S.; Kraleti, S.; Chada, A.; Ravilla, R.; Marco, A.; Shekhawat, N.S.; Montales, M.T.; Kuriakose, K.; Sasapu, A.; Beebe, A.; Patil, N.; Musham, C.K.; Lohani, G.P.; Mirza, W. Clinical Review of Antidiabetic Drugs: Implications for Type 2 Diabetes Mellitus Management. Frontiers in Enocrinology 2017, 8, 1-12, https://doi.org/10.3389/fendo.2017.00006.

17. Sulphonylureas Available online: https://www.diabetes.co.uk/diabetes-medication/sulphonylureas.html (accessed on 19 November 2020).

18. Reichal, C.; Rao, M. Anti-Diabetic Drugs and Fixed Dose Combination Therapy. Research \& Reviews: Journal of Pharmacy and Pharmaceutical Sciences 2014, 3, 55-58.

19. Asaolu, S.; Adefemi, O.S.; Oyakilome, I.G.; Ajibulu, K.E..; Asaolu, M.F. Proximate and Mineral Composition of Nigerian Leafy Vegetables. Journal of Food Research 2012, 1, 214-218, https://doi.org/10.5539/jfr.v1n3p214.

20. Yeap, S.K.; Ho, W.Y.; Beh, B.K.; Liang, W.S.; Ky, H.; Hadi, A. Vernonia Amygdalina , an Ethnoveterinary and Ethnomedical Used Green Vegetable with Multiple Bio- Activities. Journal of Medicinal Plants Research 2010, 4, 2787-2812.

21. Hirst, J.A.; Farmer, A.J.; Dyar, A.; Lung, T.W.C.; Stevens, R.J. Estimating the Effect of Sulfonylurea on HbA1c in Diabetes: A Systematic Review and Meta-Analysis. Diabetologia 2013, 56, 973-984, https://doi.org/10.1007/s00125-013-2856-6.

22. Sherifali, D.; Nerenberg, K.; Pullenayegum, E.; Cheng, J.E.; Gerstein, H.C. The Effect of Oral Antidiabetic Agents on A1C Levels: A Systematic Review and Meta-Analysis. Diabetes Care 2010, 33, 1859-1864, https://doi.org/10.2337/dc09-1727.

23. Ezuruike, U.; Prieto, J.M. Assessment of Potential Herb-DrugIinteractions among Nigerian Adults with Type2 Diabetes. Frontiers in Pharmacology 2016, 7, 1-8, https://doi.org/10.3389/fphar.2016.00248.

24. Khan, A.; Safdar, M.; Ali Khan, M.M.; Khattak, K.N.; Anderson, R.A. Cinnamon Improves Glucose and Lipids of People with Type 2 Diabetes. Diabetes Care 2003, 26, 3215-3218, https://doi.org/10.2337/diacare.26.12.3215.

25. Attanayake, A.P.; Jayatilaka, K.A.P.W.; Mudduwa, L.K.B.; Pathirana, C. $\beta$-Cell Regenerative Potential of Selected Herbal Extracts in Alloxan Induced Diabetic Rats. Current Drug Discovery Technologies 2018, 16, 278-284.

26. Abbasi, Z.; Jelodar, G.; Geramizadeh, B. Prevention of Diabetic Complications by Walnut Leaf Extract via Changing Aldose Reductase Activity: An Experiment in Diabetic Rat Tissue. Journal of Diabetes Research 2020, 2020, 1-8, https://doi.org/10.1155/2020/8982676. 
27. Yeh, G.Y.; Eisenberg, D.M.; Kaptchuk, T.J.; Phillips, R.S. Systematic Review of Herbs and Dietary Supplements for Glycemic Control in Diabetes. Diabetes Care 2003, 26, 1277-1294, https://doi.org/10.2337/diacare.26.4.1277.

28. Toyang, N.J.; Verpoorte, R. A Review of the Medicinal Potentials of Plants of the Genus Vernonia (Asteraceae). Journal of Ethnopharmacology 2013, 146, 681-723, https://doi.org/10.1016/j.jep.2013.01.040.

29. Egharevba, C.; Osayemwenre, E.; Imiehe, V.; Ahomafor, J.; Akunyuli, C. Significance of Bitter Leaf (Vernonia Amagdalina) In Tropical Diseases and Beyond: A Review. Malaria Chemotherapy Control and Elimination 2014, 03, 1-10.

30. Nursuhaili, A.B.; Nur Afiqah Syahirah, P.; Martini, M.Y.; Azizah, M.; Mahmud, T.M.M. A Review: Medicinal Values, Agronomic Practices and Postharvest Handlings of Vernonia Amygdalina. Food Research 2019, 3, 380-390.

31. Alara, O.R.; Nour, A.; Olalere, O.A. Phytochemical and Pharmacological Properties of Vernonia Amygdalina: A Review. Journal of Chemical Engineering and Industrial Biotechnology 2017, 2, 80-96, https://doi.org/10.15282/jceib.v2i1.3871.

32. Nwanjo, H.U. Efficacy of Aqueous Leaf Extract of Vernonia Amygdalina on Plasma Lipoprotein and Oxidative Status in Diabetic Rat Models. Nigerian journal of physiological sciences : official publication of the Physiological Society of Nigeria 2005, 20, 39-42.

33. Imaga, N.O.A.; Bamigbetan, D.O. In Vivo Biochemical Assessment of Aqueous Extracts of Vernonia Amygdalina (Bitter Leaf). International Journal of Nutririon and Meabolism 2013, 5, 22-27.

34. Hasibuan, P.A.Z.; Harahap, U.; Sitorus, P.; Satria, D. The Anticancer Activities of Vernonia Amygdalina Delile . Leaves on 4T1 Breast Cancer Cells through Phosphoinositide 3-Kinase ( PI3K ) Pathway. Heliyon 2020, 6, https://doi.org/10.1016/j.heliyon.2020.e04449.

35. Audu, A.S.; Taiwo, A.E.; Ojuolape, R.A. A Study Review of Documented Phytochemistry of Vernonia Amygdalina ( Family Asteraceae ) as the Basis for Pharmacologic Activity of Plant Extract. Journal of Natural Science Research 2012, 2, 1-9.

36. Adaramoye, O.A.; Akintayo, O.; Achem, J.; Fafunso, M. Lipid-Lowering Effects of Methanolic Extract of Vernonia Amygdalina Leaves in Rats Fed on High Cholesterol Diet. Vascular Health and Risk Management 2008, 4, 235-241, https://doi.org/10.2147/vhrm.2008.04.01.235.

37. Adefisayo, M.A.; Akomolafe, R.O.; Akinsomisoye, S.O.; Alabi, Q.K.; Ogundipe, O.L.; Omole, J.G.; Olamilosoye, K.P. Gastro-Protective Effect of Methanol Extract of Vernonia Amygdalina (Del.) Leaf on Aspirin-Induced Gastric Ulcer in Wistar Rats. Toxicology Reports 2017, 4, 625-633, https://doi.org/10.1016/j.toxrep.2017.11.004.

38. Dzoyem, J.P.; Kuete, V.; Eloff, J.N. Biochemical Parameters in Toxicological Studies in Africa: Significance, Principle of Methods, Data Interpretation, and Use in Plant Screenings. In: Toxicological Survey of African Medicinal Plants. Elsevier Inc., 2014; pp. 659-715, https://doi.org/10.1016/B978-0-12-800018-2.00023-6.

39. Okoduwa, R.I.S.; Umar, I.A.; James, D.B.; Inuwa, H.M. Validation of the Antidiabetic Effects of Vernonia Amygdalina Delile Leaf Fractions in Fortified Diet-Fed Streptozotocin-Treated Rat Model of Type-2 Diabetes. Journal of Diabetology 2017, 8, 74-85, https://doi.org/10.4103/jod.jod_19_17.

40. Ong, K.W.; Hsu, A.; Song, L.; Huang, D.; Tan, B.K.H. Polyphenols-Rich Vernonia Amygdalina Shows AntiDiabetic Effects in Streptozotocin-Induced Diabetic Rats. Journal of Ethnopharmacology 2011, 133, 598607, https://doi.org/10.1016/j.jep.2010.10.046.

41. Atangwho, I.J.; Egbung, G.E.; Ahmad, M.; Yam, M.F.; Asmawi, M.Z. Antioxidant versus Anti-Diabetic Properties of Leaves from Vernonia Amygdalina Del. Growing in Malaysia. Food Chemistry 2013, 141, 3428-3434, https://doi.org/10.1016/j.foodchem.2013.06.047.

42. Osinubi, A.A.A. Effects of Vernonia Amygdalina and Chlopropamide on Blood Glucose. Medical Journal of Islamic World Academy of Sciences 2007, 16, 115-119.

43. Edet, A.; Ebong, P.; Eseyin, O.; Udoh, I.; Eyo, R. Anti-Diabetic Effect and RNA Content of the Pancreas of Albino Wistar Rats Treated with Aqueous Extract of Vernonia Amygdalina Roots. International Journal of Pharma Sciences 2013, 3, 391-393.

44. Michael, U.A.; David, B.U.; Theophine, C.O.; Philip, F.U.; Ogochukwu, A.M.; Benson, V.A. Antidiabetic Effect of Combined Aqueous Leaf Extract of Vernonia Amygdalina and Metformin in Rats. Journal of Basic and Clinical Pharmacy 2010, 1, 197-202.

45. Ijeh, I.I.; Ejike, C.E.C.C. Current Perspectives on the Medicinal Potentials of Vernonia Amygdalina Del. Journal of Medicinal Plants Research 2011, 5, 1051-1061.

46. Kadiri, O.; Olawoye, B. Vernonia Amygdalina: An Underutilized Vegetable with Nutraceutical Potentials A Review. Turkish Journal of Agriculture - Food Science and Technology 2016, 4, https://doi.org/10.24925/turjaf.v4i9.763-768.570.

47. Zakaria, Y.; Azlan, N.Z.; Nik, N.F.; Muhammad, H. Phytochemicals and Acute Oral Toxicity Studies of the Aqueous Extract of Vernonia Amygdalina from State of Malaysia. Phytochemicals 2016, 4, 1-5.

48. Nwaoguikpe, R.N. The Effect of Extract of Bitter Leaf (Vernonia Amygdalina) on Blood Glucose Levels of Diabetic Rats. International Journal of Biological and Chemical Sciences 2010, 4, 721-729, https://doi.org/10.4314/ijbcs.v4i3.60500. 
49. Atangwho, I.J.; Ebong, P.E.; Eyong, E.U.; Williams, I.; Eteng, M.U.; Egbung, E. Comparative Chemical Composition of Leaves of Some Anti-diabetic Medicinal Plants: Azadirachta Indica, Vernonia Amygdalina and Gongronema Latifolium. African Journal of Biotechnology 2009, 8, 4685-4689.

50. Ezekiel, D.R.A.; Ojo, A.; Oluwafemi, O. Antioxidant Activities and Nutritional Compositions of Vernonia Amygdalina Antioxidant Activities and Nutritional Compositions of Vernonia Amygdalina. International Journal of Basic and Applied Science 2015, 4, 9-16.

51. Atangwho, I.; Ebong, P.; Eyong, E.; Eteng, M.; Uboh, F. Vernonia Amygdalina Del: A Potential Prophylactic Anti-diabetic Agent in Lipid Complication. Global Journal of Pure and Applied Sciences 2007, 13, 103-106, https://doi.org/10.4314/gjpas.v13i1.16677.

52. Yeap, S.K.; Liang, W.S.; Beh, B.K.; Ho, W.Y.; Yousr, A.N.; Alitheen, N.B. In Vivo Antidiabetic and Acute Toxicity of Spray-Dried Vernonia Amygdalina Water Extract. International Food Research Journal 2013, 20, 613-616.

53. Zakaria, Y.; Zainul Azlan, N.; Fakhuruddin Nik Hassan, N.; Muhammad, H.; Yusmazura Zakaria, C. In Vivo Antidiabetic Efficacy of Malaysian Vernonia Amygdalina Aqueous Extract. Journal of Medicinal Plants Studies 2018, 6, 72-77, https://doi.org/10.13140/RG.2.2.15416.44803.

54. Ekpo, A.; Eseyin, O.A.; Ikpeme, A.O.; Edoho, E.J. Studies on Some Biochemical Effects of Vernonia Amygdalina in Rats. Asian Journal of Biochemistry 2007, 2, 193-197, https://dx.doi.org/10.3923/ajb.2007.193.197.

55. Atangwho, I.; Ebong, P.; Eteng, M.; Eyong, E.; Obi, A. Effects of Vernonia Amygdalina Del Leaf on Kidney Function of Diabetis Rats. Journal of Pharmacology 2007, 3, 143-148, https://dx.doi.org/10.3923/ijp.2007.143.148.

56. Yazid, F.; Hasanah, N.B.; Rosmalena; Hanafi, M.; Prasasty, V.D. Anti-diabetic and Antioxidant Potential of Vernonia Amygdalina Leaf Extract in Alloxan-Induced Sprague-Dawley Rats. OnLine Journal of Biological Sciences 2020, 20, 190-200, https://doi.org/10.3844/ojbsci.2020.190.200.

57. Ajayi, G.O.; Edamisan, O.M.; Obayemi, P.T.; Elegbeleye, E.N.; Obi, E.U. Phytoconstituents and Antidiabetic Activity of Vernonia Amygdalina (Asteraceae) in Steptozotocin-Induced Diabetic Rats. International Journal of Biochemistry, Bioinformatics and Biotechnology Studies 2021, 6, 1-16.

58. Akah, P.; Alejmi, J.A.; Salawu, O.A.; Okoye, T.C.; Offiah, N.V. Effects of Vernonia Amygdalina on Biochemical and Hematological Parameters in Diabetic Rats. Asian Journal of Medicine Sciences 2009, 1, 108-113.

59. Ejiofor, I.M.I.; Zaman, K.; Das, A. Antidiabetic Evaluations of Different Parts of Vernonia Amygdalina. IOSR Journal of Pharmacy and Biological Sciences 2017, 12, 23-28.

60. Ogbuagu, E.O.; Airaodion, A.I.; Ogbuagu, U.; Airaodion, E.O. Effect of Methanolic Extract of Vernonia Amygdalina Leaves on Glycemic and Lipidaemic Indexes of Wistar Rats. Asian Journal of Research in Medical and Pharmaceutical Sciences 2019, 7, 1-14, https://doi.org/10.9734/ajrimps/2019/v7i330122.

61. Bawa, K.B.; Iyanda, A.A. Investigation of Hypoglycemic and Hypolipidemic Effects of Methanolic Extracts of Bitter Leaf [Vernonia Amygdalina Delile] in Male Rats. Asian Journal of Advanced Research and Reports 2020, 10, 30-37, https://doi.org/10.9734/ajarr/2020/v10i430250.

62. Okoduwa, S.; Umar, I.A.; James, D.B.; Inuwa, H.M.; Habila, J.D.; Venditti, A.; Okoduwa, S.I.R.; Umar, I.A.; James, D.B.; Hajiya, M. Bioguided Fractionation of Hypoglycaemic Component in Methanol Extract of Vernonia Amygdalina: An in Vivo Study. Natural Product Research 2020, 0, 1-5, https://doi.org/10.1080/14786419.2020.1805605.

63. Ntie-Kang, F.; Onguéné, P.A.; Lifongo, L.L.; Ndom, J.C.; Sippl, W.; Mbaze, L.M.A. The Potential of AntiMalarial Compounds Derived from African Medicinal Plants, Part II: A Pharmacological Evaluation of NonAlkaloids and Non-Terpenoids. Malaria Journal 2014, 13, 1-20, https://doi.org/10.1186/1475-2875-13-81.

64. Onyeji, C.O.; Igbinoba, S.I.; Olayiwola, G.; Adehin, A. Insight into Clinically Effective Herbal Antimalarial Products: Effects on Drug Metabolizing Enzymes and p-Glycoprotein. African Journal of Pharmacy and Pharmacology 2017, 12, 591-613.

65. Green, P.W.C.; Belmain, S.R.; Ndakidemi, P.A.; Farrell, I.W. Insecticidal Activity of Tithonia Diversifolia and Vernonia Amygdalina. Industrial Crops \& Products 2017, 110, 15-21, https://doi.org/10.1016/j.indcrop.2017.08.021.

66. Patočka, J. Vernonia Amygdalina: Bioactive Substances and Applications in Contemporary Medicine. Toxicology 2020.

67. Awwad, A.; Poucheret, P.; Idres, A.Y.; Bidel, L.; Tousch, D. The Bitter Asteraceae- An Interesting Approach to Delay the Metabolic Syndrome Progression. NFS Journal 2020, 18, 29-38, https://doi.org/10.1016/j.nfs.2020.01.001.

68. Alara, O.R.; Abdurahman, N.H.; Ukaegbu, C.I.; Kabbashi, N.A. Extraction and Characterization of Bioactive Compounds in Vernonia Amygdalina Leaf Ethanolic Extract Comparing Soxhlet and Microwave-Assisted Extraction Techniques. Journal of Taibah University for Science 2019, 13, 414-422, https://doi.org/10.1080/16583655.2019.1582460.

69. Sangeetha, R. Luteolin in the Management of Type 2 Diabetes Mellitus. Current Resarch in Nutrition and Food Science 2019, 07, 393-398, https://doi.org/10.12944/crnfsj.7.2.09. 
70. Jisaka, M.; Ohigashi, H.; Takagaki, T.; Nozaki, H.; Tada, T.; Hirota, M.; Irie, R.; Huffman, M.A.; Nishida, T.; Kaji, M.; Koshimizu, K. Bitter steroid glucosides, vernoniosides A1, A2, and A3, and related B1 from a possible medicinal plant, Vernonia amygdalina, used by wild chimpanzees. Tetrahedron 1992, 48, 625-632, https://doi.org/10.1016/S0040-4020(01)88123-0.

71. Jisaka, M.; Ohigashi, H.; Takegawa, K.; Hirota, M.; Irie, R.; Huffman, M.A.; Koshimizu, K. Steroid Glucosides from Vernonia Amygdalina, a Possible Chimpanzee Medicinal Plants. Phytochemistry 1993, 34, 409-413, https://doi.org/10.1016/0031-9422(93)80019-o.

72. Ohigashi, H.; Huffman, M.A.; Izutsu, D.; Koshimizu, K.; Kawanaka, M.; Sugiyama, H.; Kirby, G.C.; Warhurst, D.C.; Allen, D.; Wright, C.W.; David Phillipson, J.; Timon-David, P.; Delmas, F.; Elias, R.; Balansard, G. Toward the chemical ecology of medicinal plant use in chimpanzees: The case ofVernonia amygdalina, a plant used by wild chimpanzees possibly for parasite-related diseases. Journal of Chemical Ecology 1994, 20, 541-553, https://doi.org/10.1007/BF02059596.

73. Kamperdick, C.; Breitmaier, E.; Von Radloff, M.A. A New Steroid Saponin from Vernonia Amygdalina Del. (Compositae) [Ein Neues Steroidsaponin Aus Vernonia Amygdalina (Compositae)]. Journal für Praktische Chemie/Chemiker-Zeitung 1992, 334, 425-428, https://doi.org/10.1002/prac.19923340509.

74. Wang, J.; Song, H.; Wu, X.; Zhang, S.; Gao, X.; Li, F.; Zhu, X.; Chen, Q. Steroidal Saponins from Vernonia Amygdalina Del. and Their Biological Activity. Molecules 2018, 23, 1-11, https://doi.org/10.3390/molecules23030579.

75. El Barky, A.R.; Hussein, S.A.; Alm-Eldeen, A.A.; Hafez, Y.A.; Mohamed, T.M. Anti-diabetic Activity of Holothuria Thomasi Saponin. Biomedicine and Pharmacotherapy 2016, 84, 1472-1487, https://doi.org/10.1016/j.biopha.2016.10.002.

76. Wong, F.C.; Woo, C.C.; Hsu, A.; Tan, B.K.H. The Anti-Cancer Activities of Vernonia Amygdalina Extract in Human Breast Cancer Cell Lines Are Mediated through Caspase-Dependent and P53-Independent Pathways. PLoS ONE 2013, 8, https://doi.org/10.1371/journal.pone.0078021.

77. Jisaka, M.; Ohigashi, H.; Takegawa, K.; Koshimizu, K.; Huffman, M.A. Antitumoral and Antimicrobial Activities of Bitter Sesquiterpene Lactones of Vernonia Amygdalina, a Possible Medicinal Plant Used by Wild Chimpanzees. Bioscience, Biotechnology and Biochemistry 1993, 57, 833-834, https://doi.org/10.1271/bbb.57.833.

78. Erasto, P.; Grierson, D.S.; Afolayan, A.J. Bioactive Sesquiterpene Lactones from the Leaves of Vernonia Amygdalina. Journal of Ethnopharmacology 2006, 106, 117-120, https://doi.org/10.1016/j.jep.2005.12.016.

79. González-Molina, E.; Domínguez-Perles, R.; Moreno, D.A.; García-Viguera, C. Natural Bioactive Compounds of Citrus Limon for Food and Health. Journal of Pharmaceutical and Biomedical Analysis 2010, 51, 327-345, https://doi.org/10.1016/j.jpba.2009.07.027.

80. Mooren, F.C. Magnesium and Disturbances in Carbohydrate Metabolism. Diabetes, Obesity and Metabolism 2015, 17, 813-823, https://doi.org/10.1111/dom.12492.

81. Song, Y.; He, K.; Levitan, E.B.; Manson, J.E.; Liu, S. Effects of Oral Magnesium Supplementation on Glycaemic Control in Type 2 Diabetes: A Meta-Analysis of Randomized Double-Blind Controlled Trials. Diabetic Medicine 2006, 23, 1050-1056, https://doi.org/10.1111/j.1464-5491.2006.01852.x.

82. Aschner, J.L.; Aschner, M. Nutritional Aspects of Manganese Homeostasis. Molecular Aspects of Medicine 2005, 26, 353-362, https://doi.org/10.1016/j.mam.2005.07.003.

83. Li, L.; Yang, X. The Essential Element Manganese, Oxidative Stress, and Metabolic Diseases: Links and Interactions. Oxidative Medicine and Cellular Longevity 2018, 2018, 1-11, https://doi.org/10.1155/2018/7580707.

84. Gong, J.H.; Lo, K.; Liu, Q.; Li, J.; Lai, S.; Shadyab, A.H.; Arcan, C.; Snetselaar, L.; Liu, S. Dietary Manganese, Plasma Markers of Inflammation, and the Development of Type 2 Diabetes in Postmenopausal Women: Findings from the Women's Health Initiative. Diabetes Care 2020, 43, 1344-1351, https://doi.org/10.2337/dc20-0243. 